\title{
ANALISIS KEBUTUHAN BAHAN BAKU KAYU BULAT PADA INDUSTRI KAYU LAPIS PT. KATINGAN TIMBER CELEBES
}

\author{
Prediction of Raw Material Requirement at the Plywood Industry in PT Katingan Timber Celebes \\ Makkarennu, Beta Putranto dan M. Daniel Dessaratu
}

\begin{abstract}
The aim of this research was to predict the amounts of raw materials needed by industry for the next years. This study was conducted at the plywood industry in PT.Katingan Timber Celebes. For the purpose of the study, utilisation of raw material for five years (2004-2008) were collected. The obtained data were analyzed by using regresi with time series data. It is predicted that the amount of raw material for the industry (2009) will be $166,758.2 \mathrm{~m}^{3}$ consisting of meranti $\left(130,699.4 \mathrm{~m}^{3}\right)$ and rimba campuran $(36,053.8$ $\left.m^{3}\right)$
\end{abstract}

Key words: prediction, plywood industry, utilisation of raw material

\section{PENDAHULUAN}

Indonesia adalah salah satu negara yang memiliki hutan tropis terluas di dunia, dengan sumberdaya alam yang melimpah. Salah satu sumberdaya alam yang melimpah adalah kayu yang terdapat pada hutan alam yang tersebar di seluruh wilayah nusantara. Indonesia memiliki $10 \%$ hutan tropis dunia yang masih tersisa saat ini. Luas hutan asli Indonesia menyusut dengan kecepatan yang sangat menghawatirkan. Hingga saat ini, Indonesia telah kehilangan hutan aslinya sebesar $72 \%$. Penebangan hutan Indonesia yang tidak terkendali selama puluhan tahun menyebabkan terjadinya penyusutan hutan secara besar-besaran. Laju kerusakan hutan periode 1985-1997 tercatat 1,6 juta hektar per tahun, sedangkan pada periode 1997-2000 menjadi 3,8 juta hektar per tahun, ini menjadikan Indonesia menjadi salah satu tempat dengan tingkat kerusakan hutan tertinggi di dunia. Di Indonesia berdasarkan penafsiran citra landsat tahun 2000 terdapat 101,73 juta hektar hutan dan lahan rusak (Walhi, 2005).

Kebutuhan industri perkayuan Indonesia diperkirakan 70 juta meter kubik per tahun dengan kenaikan rata-rata sebesar 14,2\%/tahun (Pryono 2001). Sedangkan produksi kayu bulat diperkirakan hanya sebesar 25 juta meter kubik per tahun atau dengan kata lain terjadi defisit sebesar 45 juta meter kubik. Hal ini menujukkan bahwa sebenarnya daya dukung hutan sudah tidak dapat memenuhi kebutuhan kayu (Setyawati, 2003).

Menyikapi kondisi ini industri perkayuan harus memiliki strategi yang tepat dalam menjaga kelanjutan proses produksinya di tengah krisis ekonomi yang berkepanjangan. Industri perkayuan harus dapat mempertahankan kondisi dimana bahan baku kayu bulat tetap dalam kondisi yang stabil khususnya dari segi jumlah. Jika persediaan bahan baku kayu bulat terlalu besar maka industri akan mengalami kerugian, demikian pula jika persediaan bahan baku dalam jumlah yang lebih kecil dari kapasitas mesin maka industri juga akan mengalami kerugian. Agar proses produksi dapat berlangsung secara berkesinambungan, maka industri harus dapat memperkirakan seberapa besar kebutuhan bahan baku kayu bulat yang diperlukan di masa yang akan datang. Berdasarkan hal tersebut, untuk mengetahui seberapa besar kebutuhan bahan baku kayu bulat khususnya pada industri kayu lapis PT. Katingan Timber Celebes, maka diperlukan penelitian yang dapat memberikan informasi bagi industri tersebut tentang bagaimana perencanaan persediaan bahan baku yang efektif dan efisien.

Tujuan dari penelitian ini adalah meramalkan kebutuhan bahan baku kayu bulat pada PT. Katingan Timber Celebes. Hasil 
penelitian ini berguna sebagai bahan informasi bagi industri dalam upaya optimalisasi proses produksi melalui persediaan bahan baku yang efektif.

\section{BAHAN DAN METODE}

\section{Metode Pengumpulan Data}

Penelitian ini dilaksanakan selama 2 bulan, bertempat di industri kayu lapis PT. Katingan Timber Celebes, Makassar, Sulawesi Selatan. Metode pengumpulan yang dilakukan adalah:

1. Observasi

Kegiatan observasi yang dilakukan berupa pengamatan secara langsung di lapangan dan wawancara terhadap pimpinan/staf yang ditunjuk oleh pihak perusahaan untuk pengambilan data bagaimana sistem pembelian/pengadaan bahan baku yang dilakukan,

2. Pengumpulan data sekunder

Pengumpulan data sekunder pada perusahaan, berupa data umum perusahaan, sejarah singkat perusahaan, data jenis dan jumlah persediaan bahan baku, pembelian dan produksi selama 5 tahun (2004-2008), dan data sumber bahan baku.

Untuk mengetahui kebutuhan bahan baku, dilakukan analisis data berkala (time series data) dengan metode kuadrat terkecil, dengan rumus :

di mana:

$$
Y=a+b X
$$

$Y=$ peramalan kebutuhan bahan baku (Demand)

$\mathrm{a}=$ konstanta (kebutuhan rata-rata pertahun)

$b$ = besarnya perubahan $Y$ untuk satu perubahan $X$

$X$ = unit waktu (waktu)

\section{Analisis Data}

Analisis data yang digunakan dalam penelitian ini adalah:

1. Analisis deskriptif yaitu data-data yang dikumpulkan dengan cara pengamatan langsung di lapangan dan wawancara terhadap karyawan atau staf yang ditunjuk oleh pemimpin perusahaan berupa persediaan awal, perolehan dan penggunaan bahan baku kayu bulat ditabulasi dan digrafikkan.

2. Analisis time series untuk mengetahui kebutuhan bahan baku pada PT. Katingan Timber Celebes maka dilakukan analisis data berkala (time series data). Dengan menggunakan Analisis Regresi dengan model :

a. Analisis regresi

$$
\dot{Y}=B_{0}+B_{1} X_{1}+B_{2} X_{2}
$$

di mana:

$\dot{Y}=$ Peramalan Kebutuhan bahan baku baku dalam meter kubik $\left(\mathrm{m}^{3}\right)$

$\mathrm{B}_{0}=$ Persediaan awal Januari 2007

$B_{1}=$ Laju persediaan sampai akhir 2006

$B_{2}=$ Laju persediaan dari awal 2007 sampai akhir 2008

$X_{1}=-36, u /$ Januari 2004

- 35, u/ Februari 2004...

- 1, u/ Desember 2006

- 0, u/ Lainnya

$\mathrm{X}_{2}=-1, \mathrm{u} /$ Februari 2007

- 2, u/ Maret 2007...

- 23, u/ Desember 2008

- 0, u/ Lainnya

b. Indeks Musiman

$$
l_{i j}=\sum_{\substack{t \\ j=1}}^{t}
$$

$$
l_{i j}=\underline{Y i j},
$$

$Y_{i j}=$ nilai persediaan awal bulan ke $\mathrm{i}$ tahun ke j

Ýij = nilai penduga persediaan awal bulan ke i tahun ke j

c. Ramalan Kebutuhan u/ bulan ke i tahun ke j

$$
\ddot{Y i j}=I_{i j} Y_{i j}
$$

\section{HASIL DAN PEMBAHASAN}

\section{Jenis dan Asal Bahan Baku Kayu Bulat}

Jenis bahan baku kayu bulat yang digunakan terbagi kedalam tiga kelompok yaitu kelompok meranti, rimba campuran dan kayu indah. Jenis meranti terdiri atas kayu meranti 
Table 1. The summary of row materials purchase during the last 5 years (2004-2008).

\begin{tabular}{cccc}
\hline No & Tahun & Jumlah Perolehan $\left(\mathrm{m}^{3}\right)$ & Persentase Perolehan $(\%)$ \\
\hline 1 & 2004 & $16.737,69$ & 18,1 \\
2 & 2005 & $51.546,29$ & 50,47 \\
3 & 2006 & $61.952,85$ & 59,69 \\
4 & 2007 & $87.450,62$ & 62,52 \\
5 & 2008 & $57.556,13$ & 52,59 \\
\hline
\end{tabular}

merah, meranti putih, merantih kuning, nyatoh, manjau, pandan, tengkawang, palapi, mersawa, palado, kenari, majau, matoa dan pandan. Kelompok rimba campuran terdiri atas binuang, samana, ketapang, albisia, medang, duabanga, kapur, kedondong, sarangkaca, bawang, durian, jabon, keruing, mangga hutan, simponi, terap, bipa, jambu, bintangur, samar, manggis, pala hutan, lasi, merpayang, pisang-pisang, markila, kelantas, dara-dara, terentang dan pulai. Sedangkan kelompok kayu indah hanya terdiri atas jenis kayu cempaka.

PT. Katingan Timber Celebes selama lima tahun terakhir dalam memenuhi kebutuhan bahan bakunya selain bersumber dari HPH sendiri juga melakukan pembelian pada beberapa HPH lain.

Beberapa HPH lain yang menjadi sumber bahan baku PT. KTC tersebar di beberapa propinsi yakni Kalimantan Timur, Kalimantan Tengah, Maluku, Maluku Utara, Sulawesi Tengah, Sulawesi Barat, Papua, dan Papua Barat. Pada Tahun 2004,2005 dan 2006 bahan baku kayu bulat pada PT. KTC sebagian besar dari propinsi Kalimantan Timur, Maluku dan Maluku Utara. Pada Tahun 2007 bahan baku sebagian besar bersumber dari Papua, Kalimantan Timur dan Maluku. Sedangkan pada Tahun 2008 bahan baku kayu bulat pada PT. KTC diperoleh dari propinsi Kalimantan Timur, Maluku, Sulawesi Barat dan Papua.

\section{Sistem Pembelian dan Penanganan Bahan Baku}

Pengadaan kayu bulat pada PT. Katingan Timber Celebes (KTC) dilakukan dengan sistem kontrak dan dilakukan setelah mengetahui sejumlah kebutuhan bahan baku untuk produksi sesuai dengan "rencana pemenuhan bahan baku industri" atau RPBBI selama satu tahun. Adapun sistem pembeliannya menggunakan sistem one price yaitu pembelian secara partai dimana kayu bulat untuk satu partai adalah harganya sama dan tidak lagi memperhatikan jenis kayu bulat yang dibeli. Sistem pembayaran kayu bulat yang diberlakukan oleh pemasok bervariasi. Adapun sistem pembayarannya dapat dibagi menjadi dua metode yaitu:

a. Pembayaran sebesar $50 \%$ dimuka dan $50 \%$ lagi setelah kayu bulat dimuat di kapal

b. Pembayaran sebesar $25 \%$ pada saat kesepakatan kontrak, $25 \%$ pada saat kayu dimuat di kapal, 25\% setelah proses pengapalan dan $25 \%$ lagi setelah kayu bulat tiba di industri. Apabila antara pemasok dengan perusahaan saling percaya maka, pembayarannya dapat dilakukan satu bulan setelah kayu bulat tiba di industri.

\section{Perolehan dan Penggunaan Kayu Bulat}

Jenis kayu bulat yang digunakan didominasi oleh kelompok meranti dan rimba campuran dan sebagian kecil jenis kayu indah. Jumlah persediaan awal, perolehan dan penggunaan kayu bulat pada PT. KTC selama 5 tahun terakhir (2004 - 2008) dapat dilihat pada Tabel 2.

Rata-rata jumlah perolehan kayu bulat untuk ketiga kelompok jenis kayu selama 5 tahun terakhir sebesar $92370.82 \mathrm{~m}^{3}$. Berdasarkan kelompok jenis kayunya, perolehan kayu bulat yang terbesar berturut-turut sampai yang terkecil yaitu dari kelompok jenis meranti (85\%), rimba campuran (14.7\%) dan kayu indah $(0,3 \%)$ dari total perolehan kayu bulat. Perolehan kelompok jenis meranti lebih tinggi dibandingkan dengan kelompok jenis lainnya karena kebutuhan produksi untuk jenis meranti lebih besar dibandingkan dengan jenis lainnya. Hal ini disebabkan oleh sumber bahan baku jenis kayu meranti lebih banyak dari jenis kayu lainnya. 
Table 2. The summary of raw materials consumption during the last 5 years

\begin{tabular}{|c|c|c|c|c|c|c|c|c|c|}
\hline \multirow[t]{2}{*}{ Tahun } & \multicolumn{3}{|c|}{ Persediaan Awal (m3) } & \multicolumn{3}{|c|}{ Perolehan (m3) } & \multicolumn{3}{|c|}{ Pengqunaan (m3) } \\
\hline & MRT & MIX & K.IDH & MRT & MIX & K.IDH & MRT & MIX & K.IDH \\
\hline 2004 & 22986.2 & 0.0 & 0.0 & 89153.9 & 3289.5 & 0.0 & 94878.5 & 2760.6 & 0.0 \\
\hline 2005 & 17261.6 & 528.9 & 0.0 & 91914.4 & 10111.4 & 98.1 & 97739.7 & 6353.6 & 0.0 \\
\hline 2006 & 11436.2 & 4277.7 & 98.1 & 92922.9 & 9856.4 & 0.0 & 103750.6 & 12696.2 & 98.0 \\
\hline 2007 & 608.6 & 2438.0 & 0.0 & 110150.3 & 29627.6 & 79.5 & 96856.5 & 30842.7 & 79.5 \\
\hline 2008 & 13902.3 & 1212.8 & 0.0 & 92901.5 & 14869.3 & 1235.7 & 100937.2 & 13913.2 & 645.1 \\
\hline \multicolumn{4}{|c|}{ Total } & 392686.6 & 67754.2 & 1413.3 & 494162.5 & 66566.3 & 822.6 \\
\hline \multicolumn{4}{|c|}{ Rata-rata } & 78537.3 & 13550.8 & 282.66 & 98832.5 & 13313.2 & 164.5 \\
\hline
\end{tabular}

Sumber : Laporan Mutasi Kayu Bulat PT. Katingan Timber Celebes Tahun 2004-2008 (Diolah)

Rata-rata jumlah penggunaan kayu bulat (kelompok meranti, rimba campuran dan kayu indah) pada PT. Katingan Timber Celebes selama 5 tahun terakhir (2004-2008) sebesar $112310.28 \mathrm{~m}^{3}$. Berdasarkan kelompok jenisnya, rata-rata penggunaan kayu meranti sebesar $87,9 \%$, rimba campuran sebesar $12,0 \%$ dan kayu indah sebesar $0,1 \%$. Tingkat penggunaan kayu bulat untuk kelompok jenis meranti lebih besar dibandingkan dengan kelompok jenis lainnya. Hal ini antara lain diakibatkan oleh produk yang dihasilkan dari PT. KTC berbahan baku utama kayu jenis meranti, selain itu perolehan kayu bulat untuk kelompok jenis meranti dari berbagai sumber cukup tersedia. Untuk kelompok jenis rimba campuran dan kayu indah tingkat penggunaan kayu bulat sangat rendah, hal ini diakibatkan oleh sulitnya memperoleh kayu bulat jenis kelompok tersebut terutama untuk kelompok jenis kayu indah.

\section{Analisis Kebutuhan Bahan Baku}

Berdasarkan data persediaan bahan baku, maka pola persediaan bahan baku untuk jenis meranti dapat dilihat pada Gambar 1.

Dari pola persediaan diatas maka dapat diketahui bahwa pada tahun 2004-2006 laju persediaan bahan baku mengalami penurunan. Kemudian dari awal tahun 2007-2008 persediaan bahan baku mengalami kenaikan namun tidak secara signifikan. Berdasarkan persamaan regresi maka penurunan persediaan dapat diketahui sebesar $389,514 \mathrm{~m}^{3}$. Hal ini disebabkan oleh karena PT.KTC mengadakan pembelian bahan baku sesuai dengan

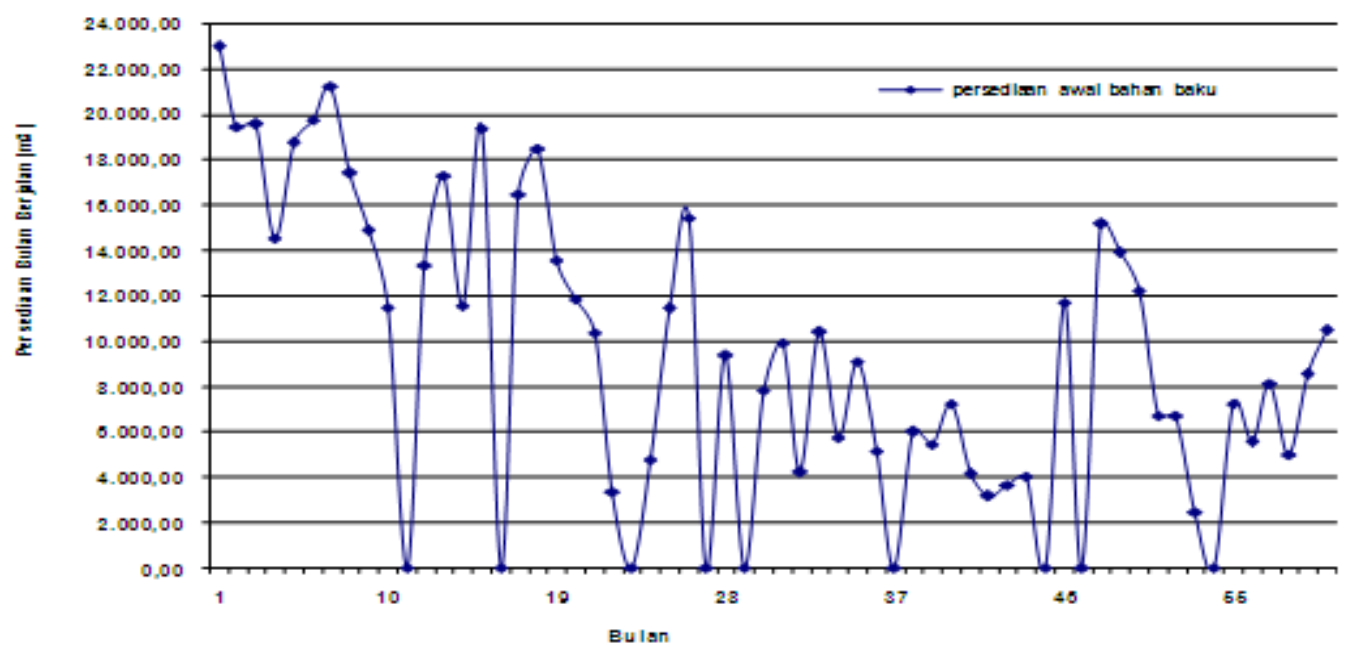

Figure 1. Pattern of raw materials inventory for shorea groups 
Table 3. Seasonal index and inventory raw materials (shorea groups) during the last 5 years (2004-2008).

\begin{tabular}{ccccccc}
\hline Bulan & Indeks & \multicolumn{5}{c}{ Persediaan Bahan Baku Kayu Bulat Jenis Meranti $\left(\mathrm{m}^{3}\right)$} \\
\cline { 2 - 6 } & Musiman & 2004 & 2005 & 2006 & 2007 & 2008 \\
\hline January & 0.99 & 22986.2 & 17261.6 & 11436,2 & 608.6 & 13902.3 \\
Februari & 1.31 & 19445.2 & 11568.4 & 15426.0 & 6013.7 & 12215.7 \\
Maret & 0.89 & 19547.3 & 19367.2 & 12517.1 & 5444.6 & 6729.5 \\
April & 1.01 & 14535.0 & 12647.2 & 9363.0 & 7208.6 & 6702.1 \\
Mei & 0.48 & 18743.8 & 16487.0 & 11255.6 & 4152.2 & 2483.2 \\
Juni & 0.29 & 19744.0 & 18487.6 & 7829.1 & 3164.8 & 678.7 \\
July & 0.72 & 21212.9 & 13538.6 & 9918.6 & 3651.1 & 7248.6 \\
Agustus & 1.63 & 17393.9 & 11857.6 & 4225.1 & 4012.5 & 5560.1 \\
September & 1.12 & 14867.4 & 10344.4 & 10387.7 & 8841.3 & 8143.6 \\
Oktober & 1.12 & 11455.6 & 3381.9 & 5747.7 & 11723.0 & 5006.7 \\
November & 2.02 & 19237.5 & 392.7 & 9110.3 & 21986.8 & 8545.8 \\
Desember & 1.63 & 13358.5 & 4756.5 & 5139.5 & 15164.1 & 10471.2 \\
\hline
\end{tabular}

permintaan pasar atau konsumen, sehingga jika jumlah permintaan mengalami penurunan maka jumlah persediaan bahan baku juga mengalami penurunan. Sedangkan pada 2007-2008 laju persediaan mengalami peningkatan sebesar $136,359 \mathrm{~m}^{3}$. Adanya peningkatan jumlah persediaan bahan baku disebabkan oleh jumlah permintaan pasar/konsumen mengalami peningkatan. Berdasarkan analisis statistik yang dilakukan maka indeks musiman bahan baku kayu bulat jenis meranti dapat diketahui seperti pada Tabel 3.
Dari tabel tersebut diatas, maka berdasarkan analisis statistik ramalan kebutuhan bahan baku kayu bulat jenis meranti pada tahun 2009 dapat diketahui dengan menggunakan persamaan $\ddot{Y}_{i j}=l_{i j} Y_{i j}$. Dari persamaan tersebut diperoleh hasil peramalan kebutuhan bahan baku kayu bulat terlihat pada Tabel 4.

Untuk jenis rimba campuran, berdasarkan data persediaan bahan baku (lampiran 7-11) pola persediaannya dapat dilihat pada Gambar 2.

Table 4. Prediction of raw material requirement for shorea groups in 2009

\begin{tabular}{|c|c|c|}
\hline No & Bulan & Kebutuhan Bahan Baku (m³) \\
\hline 1 & Januari & 8974.99 \\
\hline 2 & Februari & 12054.63 \\
\hline 3 & Maret & 8311.14 \\
\hline 4 & April & 9569.47 \\
\hline 5 & Mei & 4613.318 \\
\hline 6 & Juni & 2534.33 \\
\hline 7 & Juli & 7116.34 \\
\hline 8 & Agustus & 16332.86 \\
\hline 9 & September & 11375.29 \\
\hline 10 & Oktober & 11528.02 \\
\hline 11 & November & 21067.05 \\
\hline 12 & Desember & 17221.92 \\
\hline \multicolumn{2}{|c|}{ Total } & 130699.4 \\
\hline
\end{tabular}




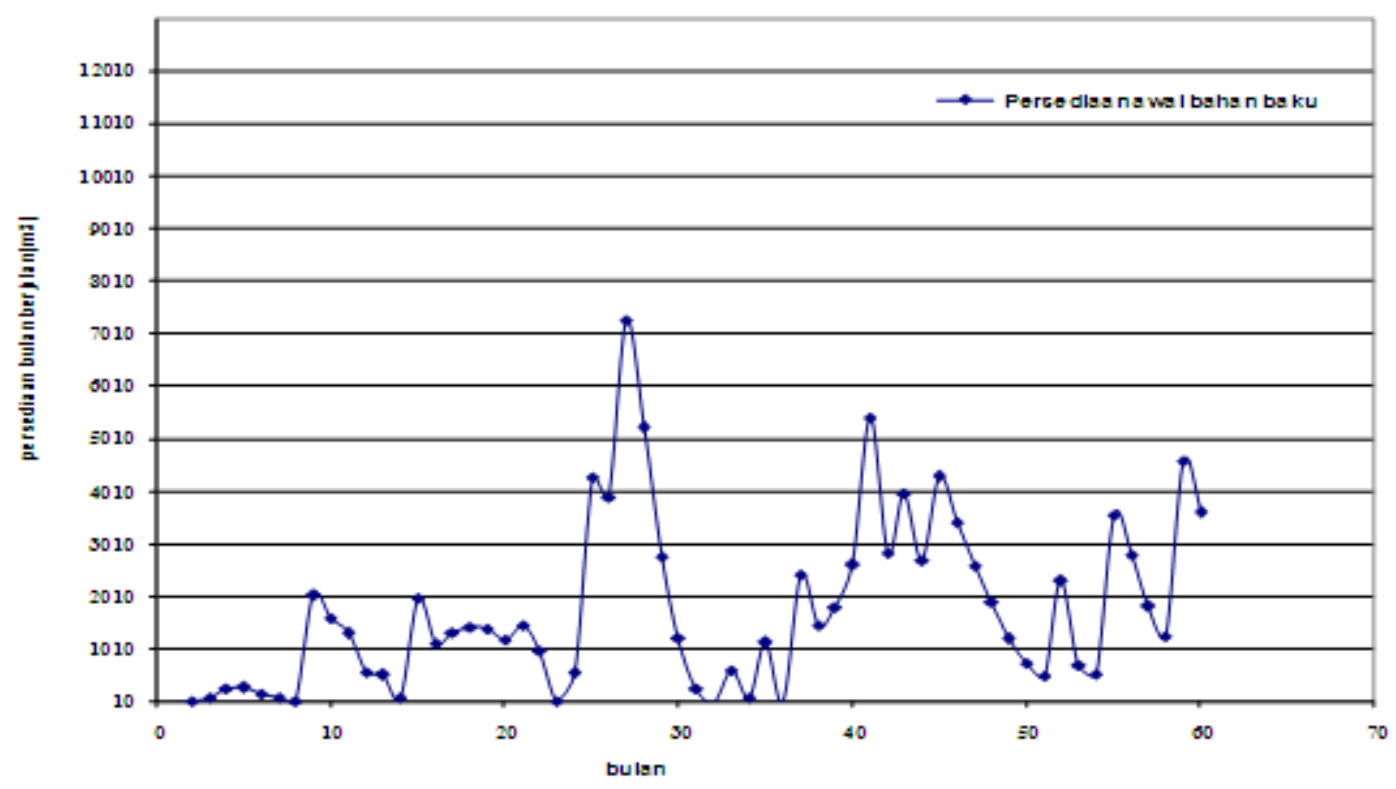

Figure 2. Pattern of raw materials inventory for muxed species during the last 5 years

Berdasarkan analisis statistik, dari laju persediaan dan penggunaan bahan baku kayu bulat dapat di ketahui indeks musiman bahan baku kayu bulat jenis rimba campuran seperti pada tabel berikut.

Table 5. Seasonal index and inventory raw materials (mixed species) during the last 5 years (20042009).

\begin{tabular}{|c|c|c|c|c|c|c|}
\hline \multirow{2}{*}{ Bulan } & \multirow{2}{*}{ Indeks Musiman } & \multicolumn{5}{|c|}{ Persediaan Bahan Baku Kayu Bulat Jenis Rimba Campuran $\left(\mathrm{m}^{3}\right)$} \\
\hline & & 2004 & 2005 & 2006 & 2007 & 2008 \\
\hline January & 0.63 & 0.0 & 528.9 & 4277.7 & 2438.0 & 1212.8 \\
\hline Februari & 0.57 & 17.2 & 98.6 & 3911.5 & 1467.1 & 739.5 \\
\hline Maret & 1.07 & 86.4 & 1979.8 & 7271.2 & 1821.0 & 518.0 \\
\hline April & 0.86 & 264.1 & 1115.9 & 5227.2 & 2622.6 & 2313.4 \\
\hline Mei & 1.06 & 280.1 & 1325.0 & 2772.9 & 5430.6 & 704.8 \\
\hline Juni & 1.19 & 168.8 & 1431.0 & 1221.8 & 2844.2 & 553.0 \\
\hline July & 0.87 & 90.9 & 1412.4 & 278.3 & 3981.4 & 3563.6 \\
\hline Agustus & 0.61 & 26.4 & 1185.9 & 0.0 & 2711.0 & 2798.7 \\
\hline September & 0.92 & 2036.8 & 1461.2 & 607.6 & 4298.7 & 1825.8 \\
\hline Oktober & 1.25 & 1597.5 & 993.5 & 91.8 & 3425.8 & 1270.8 \\
\hline November & 0.84 & 1316.5 & 35.9 & 1144.6 & 2605.8 & 4587.8 \\
\hline Desember & 0.57 & 579.0 & 565.2 & 8.6 & 1916.6 & 3622.6 \\
\hline
\end{tabular}

Dari tabel tersebut diatas maka, ramalan kebutuhan bahan baku kayu bulat jenis rimba campuran padat tahun 2009 dapat diketahui berdasarkan analisis statistik dari persamaan $\ddot{Y}_{i j}$ = lij $x$ Ýij sebagai berikut: 
Tabel 6. Prediction of raw material requirement for mixed species in 2009

\begin{tabular}{rlr}
\hline No & Bulan & $\begin{array}{r}\text { Kebutuhan Bahan } \\
\text { Baku tahun } 2009 \\
\left(\mathrm{~m}^{3}\right)\end{array}$ \\
\hline 1 & Januari & 2147.12 \\
2 & Februari & 1812.86 \\
3 & Maret & 3462.87 \\
4 & April & 2831.29 \\
5 & Mei & 3548.96 \\
6 & Juni & 4050.69 \\
7 & Juli & 3010.04 \\
8 & Agustus & 2144.57 \\
9 & September & 3285.83 \\
10 & Oktober & 4534.28 \\
11 & November & 3093.97 \\
12 & Desember & 2131.32 \\
& Total & 36053.8 \\
\hline
\end{tabular}

Untuk bahan baku jenis kayu Indah jumlah perolehannya sangat kecil atau sebesar $0,3 \%$ dari rata-rata perolehan kayu bulat pada PT.KTC selama lima tahun terakhir. Pada tahun 2004 dan 2006 industri tidak memperoleh kayu jenis ini, sedangkan pada tahun 2005, 2007 dan 2008 perolehan kayu jenis ini secara berturutturut adalah $98.1 \mathrm{~m}^{3}, 79,5 \mathrm{~m}^{3}$ dan $1232.3 \mathrm{~m}^{3}$. Dari data perolehan tersebut maka dapat diketahui bahwa industri tidak melakukan pembelian bahan baku kayu indah secara berkesinambungan $\mathrm{Hal}$ ini disebabkan oleh sulitnya memperoleh bahan baku jenis kayu tersebut. Kalaupun bahan bakunya tersedia tetapi jumlahnya sangat kecil, sehingga pihak industri terkadang tidak melakukan pembelian bahan baku kayu jenis tersebut karena hal ini dianggap dapat merugikan industri. Dilihat dari persediaan dan perolehan bahan baku kayu bulat jenis kayu indah pada PT. KTC selama lima tahun terakhir tampak bahwa pembeliannya hanya beberapa kali saja dan dalam jumlah yang kecil.

\section{KESIMPULAN DAN SARAN}

\section{Kesimpulan}

Dari hasil penelitian dan pembahasan, maka dapat ditarik kesimpulan bahwa ramalan kebutuhan bahan baku kayu bulat PT. KTC pada tahun 2009, untuk bahan baku kayu bulat jenis meranti dibutuhkan sebanyak 130699.4 $\mathrm{m}^{3}$, sedangkan kebutuhan bahan baku kayu bulat jenis rimba campuran sebesar 36053.8 $\mathrm{m}^{3}$.

\section{Saran}

Untuk menetapkan dan menjamin tersedianya bahan baku, maka sebaiknya diadakan penelitian lanjutan mengenai sistem persediaan bahan baku yang efektif sehingga proses produksi dapat berlangsung.

\section{DAFTAR PUSTAKA}

Setyawati D. 2003. Komposit Serbuk Kayu Plastik Daur Ulang: Teknologi Alternatif Pemanfaatan Limbah Kayu dan Plastik. http://tumoutou.net/702_07134/Dina_Setyaw ati.htm [12Maret 2009]

Pryono SKS. 2001. Komitmen Berbagai Pihak dalam Menanggulangi Illegal Logging. Kongres Kehutanan Indonesia III. Jakarta

[Walhi] Wahana Lingkungan Hidup. 2005. Membangun Bencana Kehutanan: Setahun Kebijakan SBY-JK pada Sektor Kehutanan. http.//www.Walhi or.id [7 Maret 2009]

Diterima : 22 April 2009

Makkarennu, Beta Putranto, dan M. Daniel Dessaratu

Lab. Pemanfaatan dan Pengolahan Hasil Hutan

Department of Forestry, Forestry Faculty

Hasanuddin University - Indonesia 